\title{
ASSESSMENT OF DAYLIGHT IN THE SELECTED OFFICE THROUGH SIMULATION PROGRAMS: A CASE STUDY
}

Professional paper / Stručni rad

\section{Erika Dolnikova}

(Received: 13 February 2019; accepted: 27 May 2019)

Department of Building Physics, Institute of Architectural Engineering, Faculty of Civil Engineering, Technical University of Kosice, Slovakia, PhD.

Corresponding author: erika.dolnikova@tuke.sk

\begin{abstract}
An important aspect of building design is to let the daylight into rooms and create a visual comfort. Visual comfort is a psychophysical condition needed for efficient work and rest, complying with the hygienic requirements, and depends on luminous intensity, illuminance, architectural design of the space, and eyes condition. Natural light increases productivity, improves mood, and helps to save energy and workers must feel a connection with the exterior environment. The room is lit by daylight through a window on the outside wall. The results show that a zone with sufficient illumination reaches only about one third of the depth of the place where both places are located. Furthermore, evaluation of different positioning of the table revealed that only one of the investigated areas was suitable, with good visual comfort and no glare.
\end{abstract}

Keywords: lighting conditions; office; computational simulation; daylight factor; indoor environment

\section{PROCJENA DNEVNOG SVJETLA U ODABRANOM UREDU PROGRAMOM SIMULACIJE: STUDIJA SLUČAJA}

Sažetak: Važan dio projektiranja zgrada je pustif dnevno svjetto u prostore i stvoriti vizualnu udobnost. Vizualna udobnost je psihofizičko stanje ugode koje je potrebno za učinkovito održavanje higijene rada i odmora, što ovisi o intenzitetu svjetlost, razini osvijetjenosti, arhitektonskom oblikovanju prostora i stanju vida. Prirodno svjetlo povećava produktivnost, poboljšava raspoloženje i štedi energiju, a djelatnicima daje osjećaj povezanosti $\mathbf{s}$ vanjskim prostorom. Prostorija je osvijetjena dnevnim svjettom kroz prozor vanjskog zida. Rezultati pokazuju da zona s dovoljno osvjetjenja dopire samo do trećine dubine prostora gdje se nalaze oba promatrana mjesta. Nadalje, ocjenjivano je različito pozicioniranje stola u prostoriji. Na temelju rezultata, samo je jedna od promatranih pozicija prikladno osvijetjena. U toj poziciji nije bilo blještanja i postignuta je dobra vizualna udobnost.

Ključne riječi: uvjeti osvjetjenja; ured; računalna simulacija; faktor dnevne svjettosti; unutarnji okoliš 


\section{INTRODUCTION}

Daylighting a building means introducing the natural light into a building. To maximize the benefits of the natural light, it is vital to expand the interpretation of day lighting., A building's holistic energy strategy should include producing interiors that truly work for owners and occupants rather than it being a question whether to include the day lighting measures [1].

Unmanaged direct sunlight can cause disruptive or disabling glare, may lead to an overreliance on the aircooling systems, increase the energy usage and running costs, and cause low humidity and uncomfortable air quality [1].

Layouts need to be designed to balance the artificial and the natural light, taking into consideration the façade reflection, the sun's movement, the glare, the shading, the light intensity and the automation. It ensures that the spaces are evenly lit, there is good patternation, and the external and the internal elements work together.

Most importantly, the lighting needs to suit the functions and the needs of the occupants. Offices on the hand have different specific requirements [1].

Quality of day lighting and the correct selection of materials to provide controlled natural day lighting are therefore essential. Daylighting is the practice of allowing a controlled amount of natural light into a building to reduce electric lighting costs. Adequate levels of daylight throughout the day are not always possible due to the ever-changing position of the sun, window orientation, and other factors. This is where a greater understanding of daylight design comes in [2, 3].

A day lighting system includes skylights and windows along with a daylight-responsive lighting control system. Such a system can reduce energy costs by as a much as $33 \%$. Along the passage of light through the atmosphere, some wavelengths are absorbed by oxygen, ozone, water vapors, and carbon dioxide $[4,5]$.

Figure 1 shows the observed spectral distribution of sunlight on earth. Highest thermal radiation from the sun is observed at $550 \mathrm{~nm}$ wavelength.

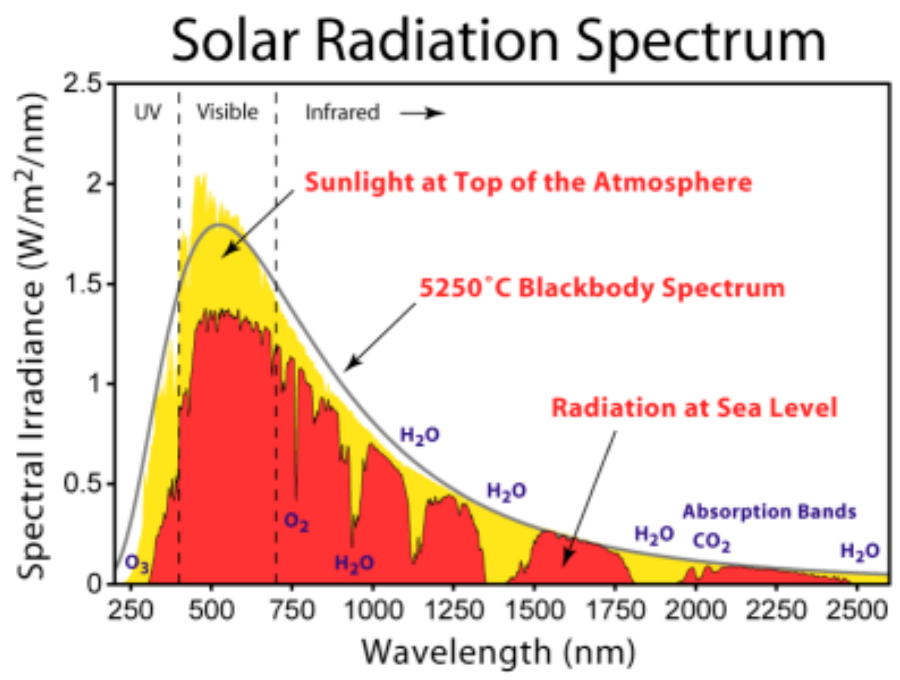

Figure 1 Spectrum of solar radiation [6]

In this study, the selected office was investigated and different positions were evaluated in terms of daylight and glare. The optimal position of the place was then evaluated by simulation in terms of both daylight and visual comfort.

\section{DAYLIGHT REQUIREMENTS IN INTERNAL SPACES}

The quantitative aspect of daylight illumination means enough daylight for securing visual activity. The quantitative level of daylight is expressed by the daylight factor $[6,7]$.

Daylight factor is the ratio of the internal light level to the external light level (see Figure 2):

$$
D F=\frac{\text { Internal illumunance }}{\text { External illuminance }} * 100 \%
$$

Dolnikova, E 
The Daylight factor is a combination of three separate components (see Figure 3) [6]:

- The sky component - the light received directy from the sky (SC)

- The externally reflected component - the light received directly by reflection from the buildings and the obstructions outside the room (ERC)

- The internally reflected component - the light received from the surfaces inside the room (IRC)

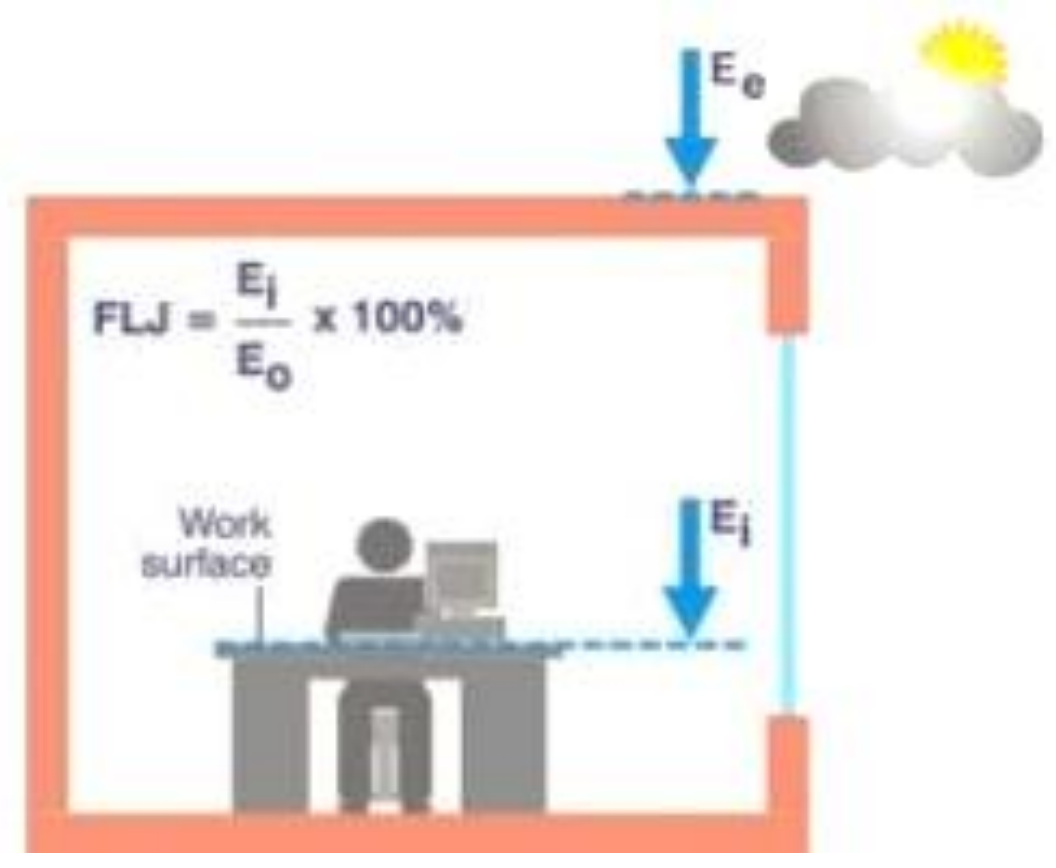

Figure 2 Daylight factor [6]

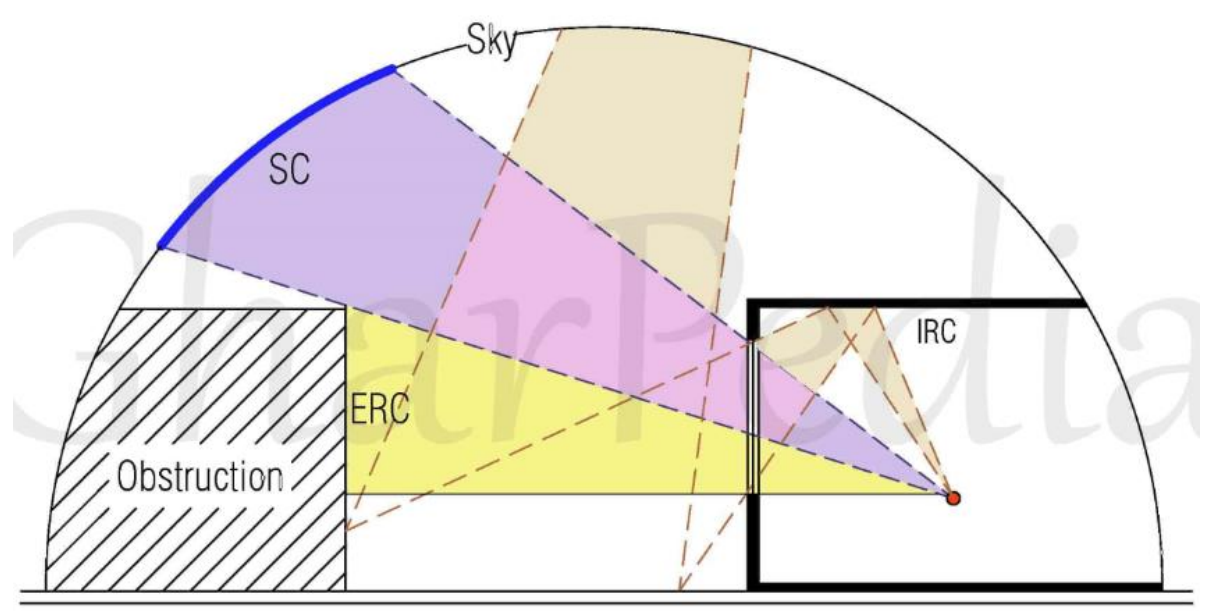

Figure 3 Sources of Daylight at a point within a room [7]

The classification of the internal day lighting indoor environment, according to Slovak and Czech's technical standards, is based on the work, its complexity, and the basic requirements placed on the complexity of the visual activity (see Table 1) [8-10].

\section{Dolnikova, $\mathrm{E}$}


Table 1 Classification of human eye recognition of visual detail tasks [10]

\begin{tabular}{|c|c|}
\hline $\begin{array}{l}\text { Human eye recognition } \\
\text { category }\end{array}$ & Visual detail tasks \\
\hline Extreme accuracy & $\begin{array}{l}\text { The most accurate visual work with a limited use of magnification, } \\
\text { a requirement to eliminate errors in definition, stringent control }\end{array}$ \\
\hline High accuracy & $\begin{array}{l}\text { Very precise activities involving production and control, high-precision } \\
\text { drawing, hand engravings with very fine detailing, fine art work }\end{array}$ \\
\hline Precise operations & $\begin{array}{l}\text { Precision manufacturing and inspection, regular drawing, technical drawing, } \\
\text { laboratory, labour-intensive investigations, fine sewing, embroidery }\end{array}$ \\
\hline Medium accuracy & $\begin{array}{l}\text { Medium precision manufacturing and inspection, reading, writing (by hand } \\
\text { and machine), routine laboratory work, examinations, treatments, using } \\
\text { machines, thicker sewing, knitting, laundry, cooking class, reading, teaching } \\
\text { cabinet, kitchen, surgery, office, meeting room, conference room }\end{array}$ \\
\hline Low accuracy & $\begin{array}{l}\text { Approximate works, manipulating objects and materials, food consumption } \\
\text { and service, leisure activities, physical education, dining room, living room, } \\
\text { lounge, hall, gymnasium, swimming pool, storage room, waiting room }\end{array}$ \\
\hline Very rough work & $\begin{array}{l}\text { Maintenance and cleaning, showering and washing, changing, walking on } \\
\text { public roads, cloakroom, toilets, corridors }\end{array}$ \\
\hline Only spatial orientation & Walking, material transport, storage of raw materials, supervision \\
\hline
\end{tabular}

Technical lighting requirements for daylight are specified by the standard STN 73 0580-1 Daylighting of buildings. Part 1: Essential requirements [11].

\section{EXPERIMENTAL SETTING}

Measurements were performed in a typical office room in Košice. A third floor south facing office was selected with interior dimensions $3.5 \mathrm{~m} \times 5 \mathrm{~m} \times 2.7 \mathrm{~m}$ and the height of the parapet $900 \mathrm{~mm}$. The room had side lighting created by a window with dimensions $1200 \mathrm{~mm} \times 2100 \mathrm{~mm}$.

The fenestration systems are created by double plastic glass. For calculations, the following coefficients were considered (transmittance coefficient 0.8 , maintenance factor of glazing on the exterior surface 0.9, maintenance factor of glazing on the interior surface 0.85 , reflectance factor of ground 0.15 (dark ground)). The walls and the ceiling were white in color with a reflectance factor of 0.7 and the floor had a reflectance factor of 0.2 . The working plane was $0.75 \mathrm{~m}$ high (desk height). Light loss coefficient due to window construction was $T=0.63$. The neighboring objects at a distance did not shade the room.

The room being used for medium-precision production was classified in IV. light - technical class (see Table 1). With the given lighting system, at the critical point of the functional place on the horizontal plane, the following values are required: minimum standard value of daylight factor $D_{\min }=1.5-2 \%$, average daylight factor $D_{\text {average }}=5-$ $6 \%$, and uniformity of the illumination more than $0.2-0.3$ for given visual task. [9-12].

An illumination of minimum $300 \mathrm{~lx}$ is recommended for most of the room area meeting the target climate-based daylight factor and $500 \mathrm{~lx}$ for the areas where productive work is performed. On the selected days, the value of the outside light ranged from 6.500-8.000 Ix in January, 7.500-10.000 Ix in February-March, and 25.000 Ix in April. Exterior horizontal illumination of $5000 \mathrm{~lx}$ was considered for the simulation program [13, 14].

Daylight measurements were performed according to Slovak standard "Measurements of day lighting." The instruments used were two Data loggers, ALMEMO 2690-10A, and illuminance sensor ALMEMO FLA 623VL with the production number 15061543 , accuracy of $5 \%$, and reflection of 0.847 . Luminance meter LS-110 was used to measure the luminance with an accuracy of $2 \%$. 


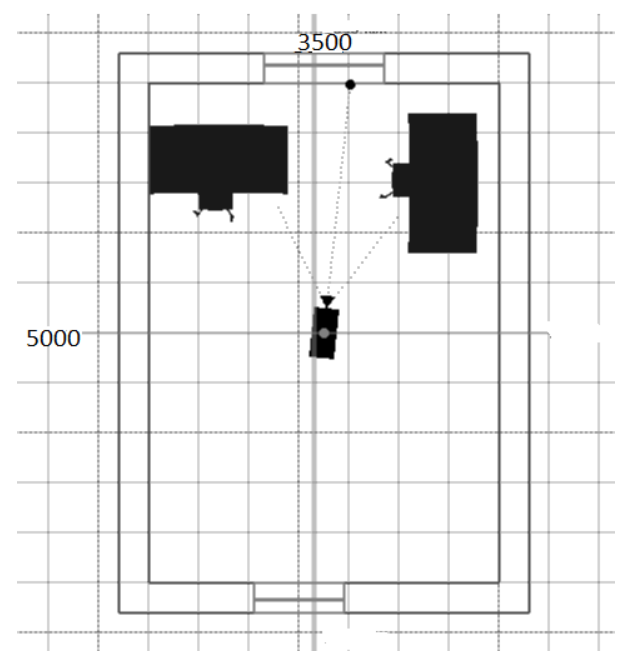

a

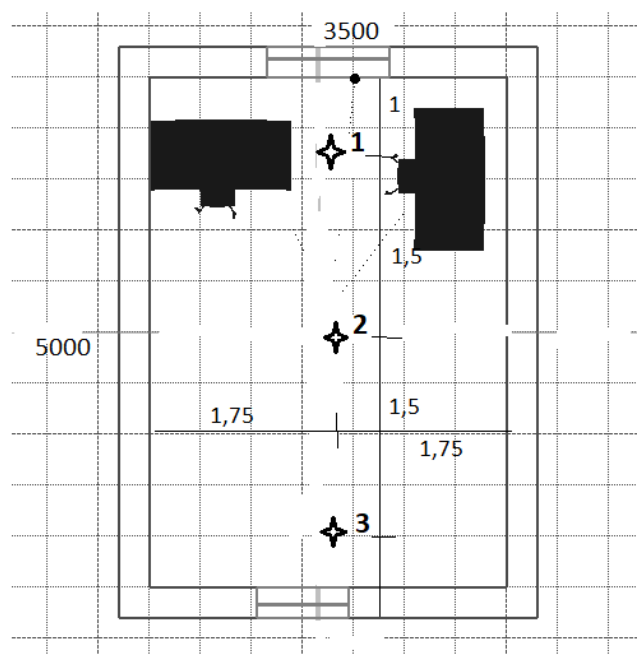

b

\subsection{Results}

Figure 4 Plan of the test office room

This article presents the measurement results for control point $A$ (shown in Figure 4a) for three days in January (shown in Figure 6), for eight days in February-March (shown in Figure 11), and one day for points $A$ and $B$ and 1-3 (shown in Figure $4 b$ ) in April. The measured sky conditions rating the gradations of sky luminance in January are shown in Figure $5(a, b)$ and for February and March are shown in Figure $5(c, d)$. In Figure $5 x$ refers to the elevation angle, $y$ refers to the Le/Lz ratio, Le refers to the external sky luminance, and LZ refers to the sky luminance at an angle of $Z 15^{\circ}$ and $45^{\circ}$; (a) the beginning of measurements in January (b) the end of measurements in January (c) the beginning of measurements in February and March (d) the end of measurements in February and March.

For illuminance analysis, the Perez sky model was used in the software, using weather data as the source for sky condition information. Day lighting simulations were performed with Velux Daylight Visualizer 3. The results of illumination, DF lighting, and luminance calculated and can be seen in Figure 12 and 13.

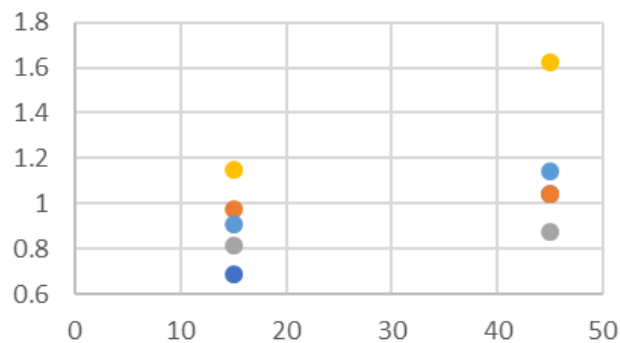

- V Le/Lz • Z Le/Lz $\bullet \mathrm{S} L e / L z \bullet J \mathrm{Le} / \mathrm{Lz} \bullet \mathrm{J}$ average

a)

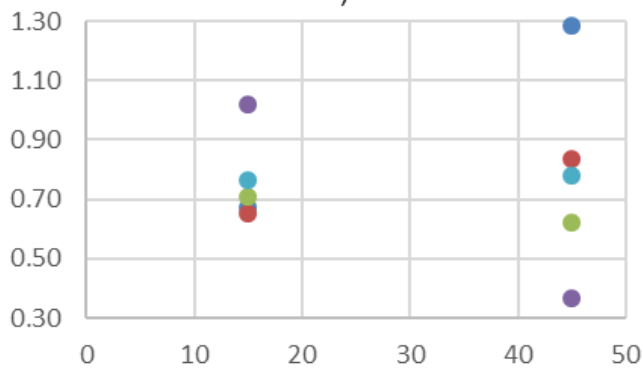

$\bullet \mathrm{ELe} / \mathrm{Lz} \bullet \mathrm{W} \mathrm{Le} / \mathrm{Lz} \bullet \mathrm{N} \mathrm{Le} / \mathrm{Lz} \bullet \mathrm{S} \mathrm{Le} / \mathrm{Lz} \bullet$ average c)

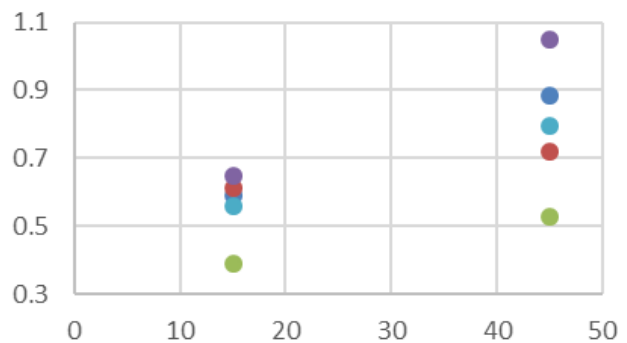

$\bullet \mathrm{V}$ Le/Lz $\bullet \mathrm{Z}$ Le/Lz $\bullet \mathrm{S} L \mathrm{Le} / \mathrm{Lz} \bullet \mathrm{J} \mathrm{Le} / \mathrm{Lz} \bullet \mathrm{J}$ average

b)

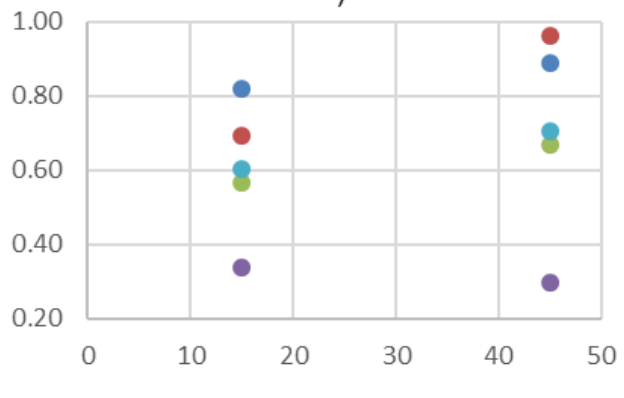

d)

Figure 5 Measured sky conditions rating the gradations of sky luminance

Dolnikova, E 


\section{1st day 10.1.2019}

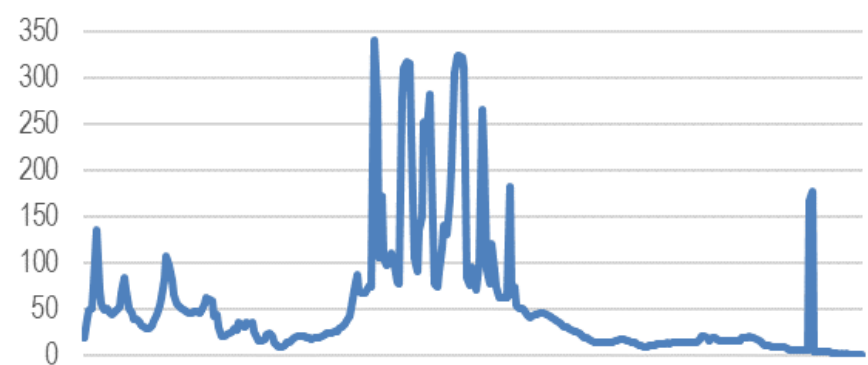

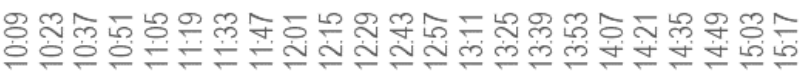

2nd day 11.1.2019
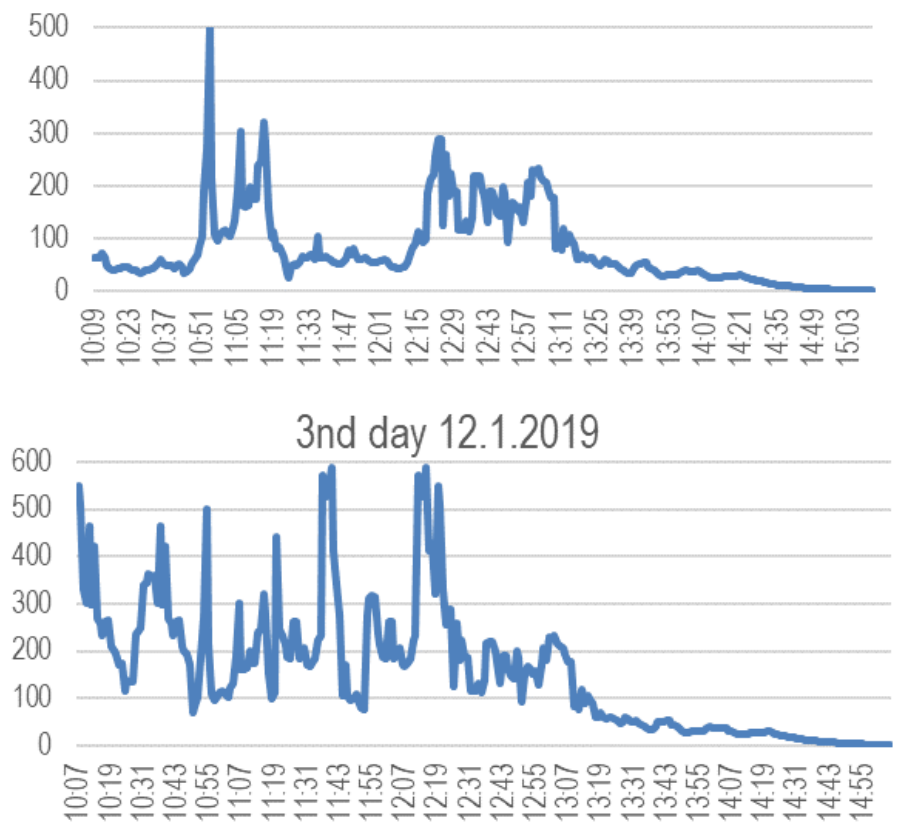

Figure 6 Measured values of illuminance level (Ix) in January

Table 2 Calculated values from the measured values of Daylight factor (\%) in January

\begin{tabular}{cccc}
\hline $1^{\text {st }}$ day & & & \\
\hline & $D_{\min }$ & $D_{\max }$ & $D_{\text {average }}$ \\
$10-12$ & 0.12 & 2.09 & 0.61 \\
$12-13$ & 0.95 & 5.25 & 2.31 \\
$13-15$ & 0.05 & 2.72 & 0.32 \\
\hline $2^{\text {nd }}$ day & & & \\
\hline & $D_{\min }$ & $D_{\max }$ & $D_{\text {average }}$ \\
$10-12$ & 0.38 & 6.25 & 1.31 \\
$12-13$ & 0.68 & 4.26 & 2.15 \\
$13-15$ & 0.03 & 2.72 & 0.67 \\
\hline $3^{\text {rd }}$ day & & & \\
\hline & $D_{\min }$ & $D_{\max }$ & $D_{\text {average }}$ \\
$10-12$ & 1.06 & 7.36 & 3.39 \\
$12-13$ & 1.34 & 7.36 & 3.21 \\
$13-15$ & 0.03 & 3.34 & 0.66 \\
\hline
\end{tabular}

Dolnikova, E 


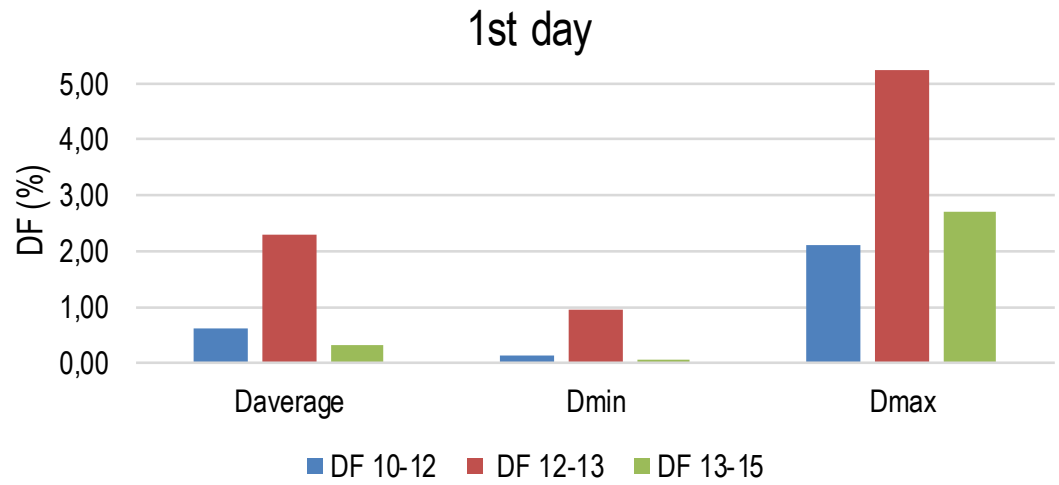

Figure 7 Graph of calculated values from the measured values of Daylight factor (\%) in January
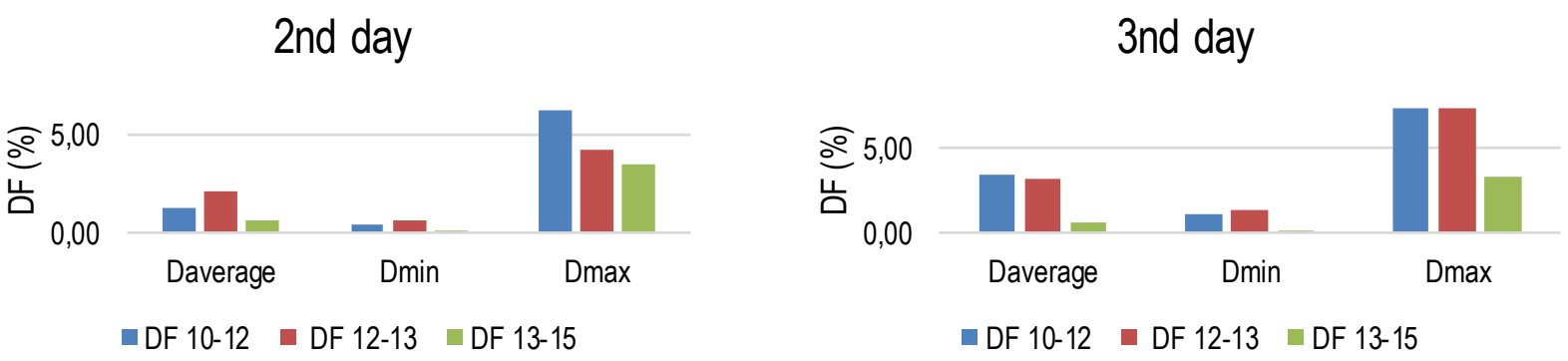

Figure 8 Graph of the calculated values from the measured values of Daylight factor (\%; on selected days in January

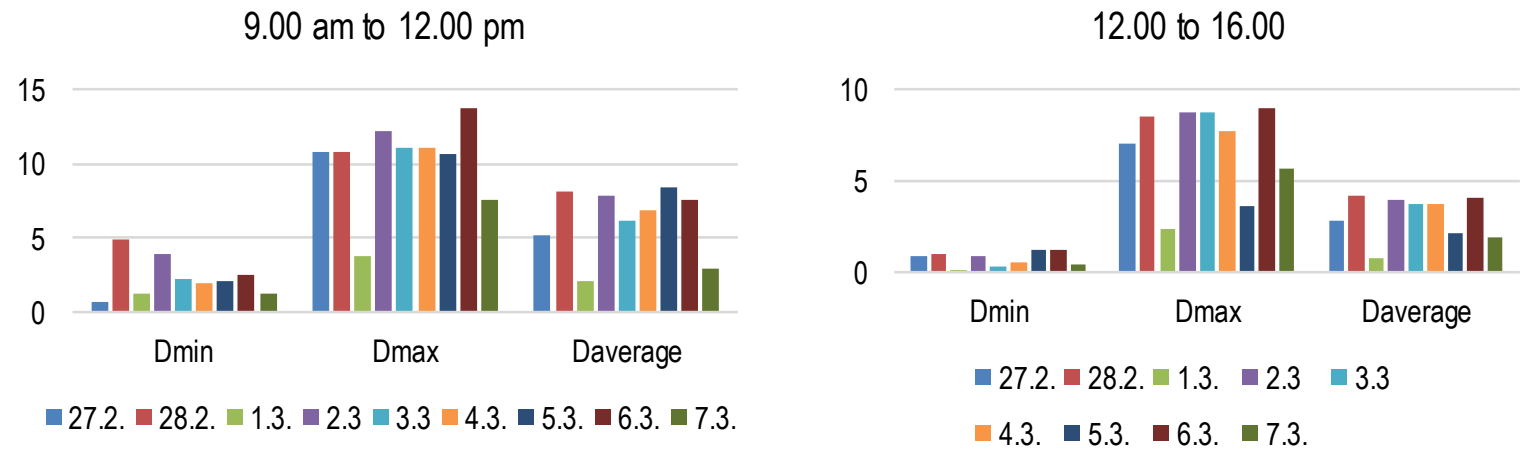

Figure 9 Calculated values from the measured values of Daylight factor (\%) in February-March

Table 3 Calculated values from the measured values of Daylight factor (\%) in April

\begin{tabular}{ccc}
\hline Control point 1 & & \\
\hline$D_{\min }$ & $D_{\max }$ & $D_{\text {average }}$ \\
6.0 & 6.37 & 6.19 \\
\hline Control point 2 & & \\
\hline$D_{\min }$ & $D_{\max }$ & $D_{\text {average }}$ \\
0.86 & 1.72 & 1.2 \\
\hline Control point 3 & & \\
\hline$D_{\min }$ & $D_{\max }$ & $D_{\text {average }}$ \\
0.54 & 0.7 & 0.61
\end{tabular}


Table 4 Calculated values from the measured values of Daylight factor (\%) in April

Control point A

\begin{tabular}{ccc}
\hline$D_{\min }$ & $D_{\max }$ & $D_{\text {average }}$ \\
6.23 & 14.91 & 9.06 \\
\hline Control point B & & \\
\hline$D_{\min }$ & $D_{\max }$ & $D_{\text {average }}$ \\
1.60 & 1.96 & 1.74 \\
\hline 5.4 .2019 & & 5.4 .2019
\end{tabular}

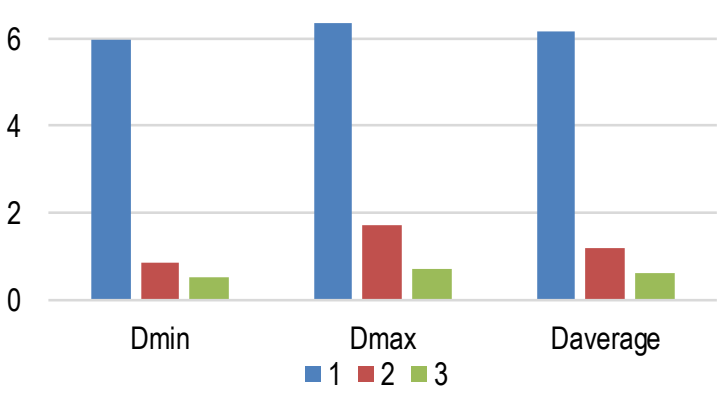

Control points 1,2 and 3

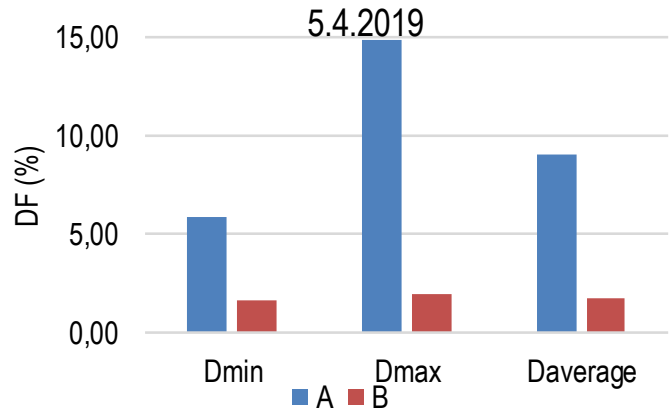

Control points $A$ and $B$

Figure 10 Calculated values from the measured values of Daylight factor (\%) in April

28.2.2019

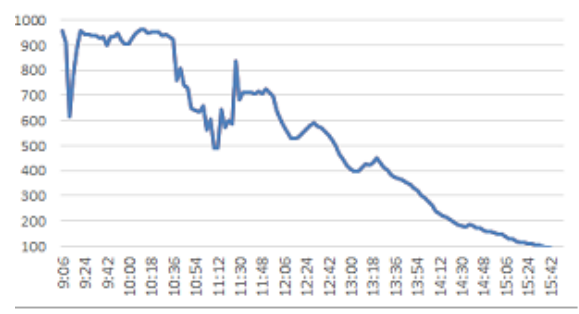

2.3.2019

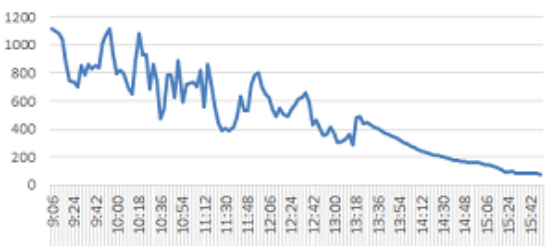

4.3.2019

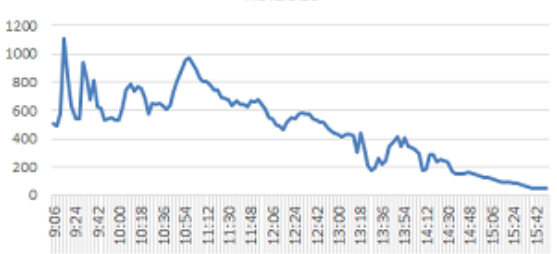

6.3 .2019

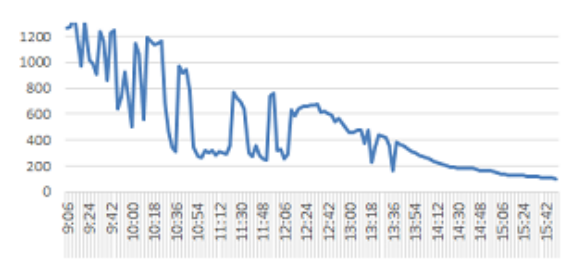

1.3.2019

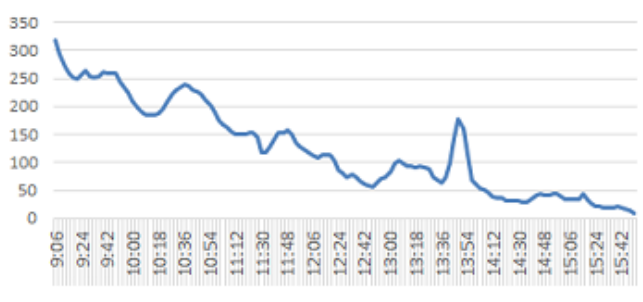

3.3.2019

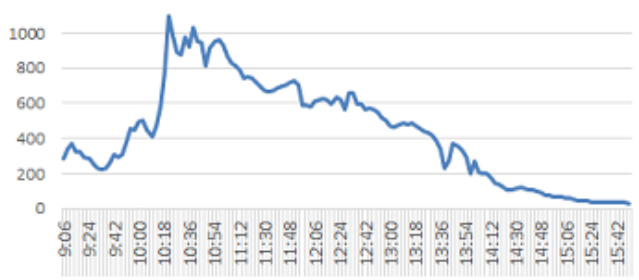

5.3 .2019

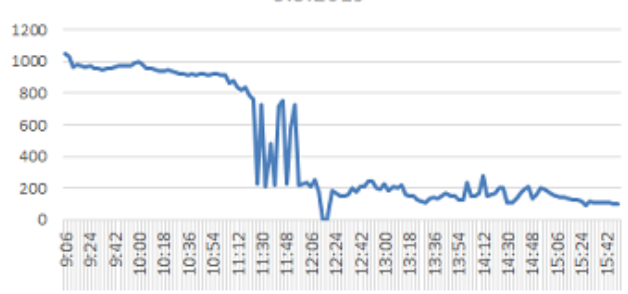

7.3.2019

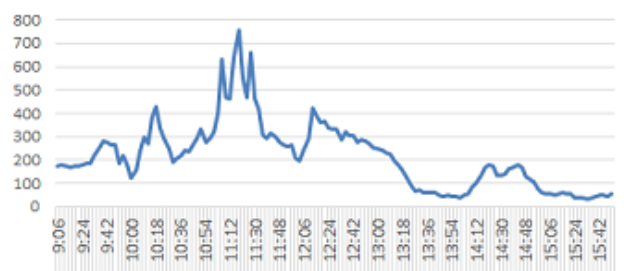

Figure11 Measured values of illuminance level (Ix) in February-March

\section{Dolnikova, E}


Assessment of daylight in the selected office through simulation programs: a case study

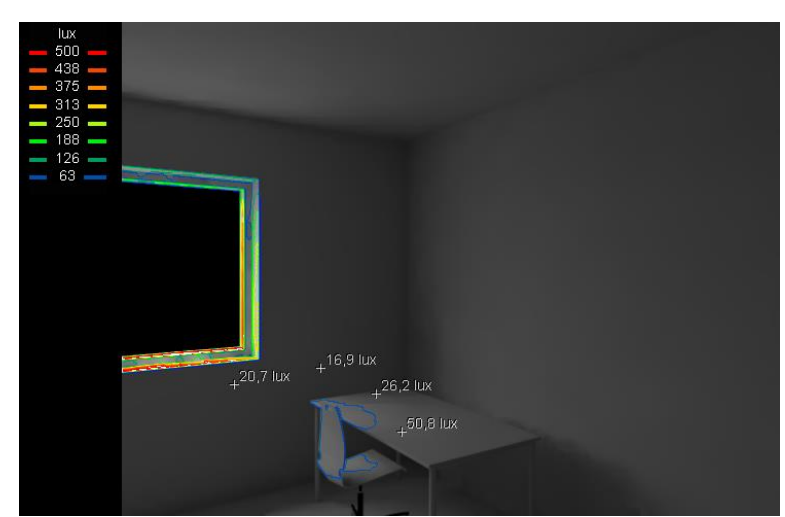

a - overcast sky, southeast view - point A; January

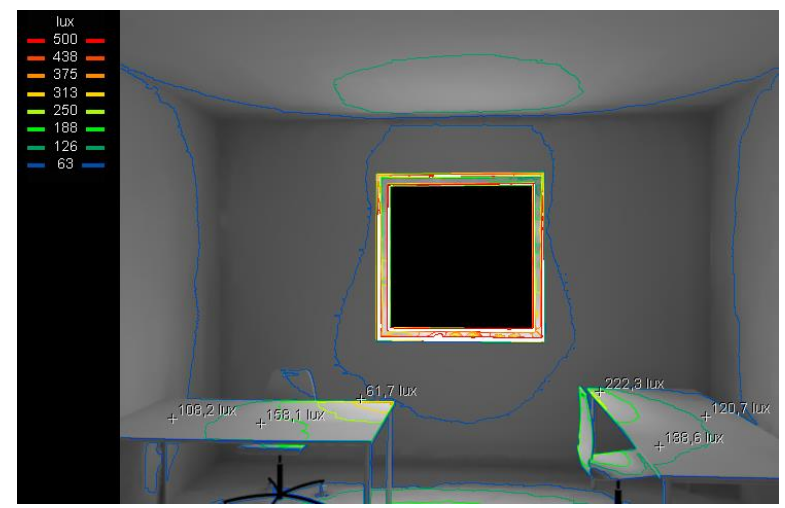

c - overcast sky, south view - points A and B; April

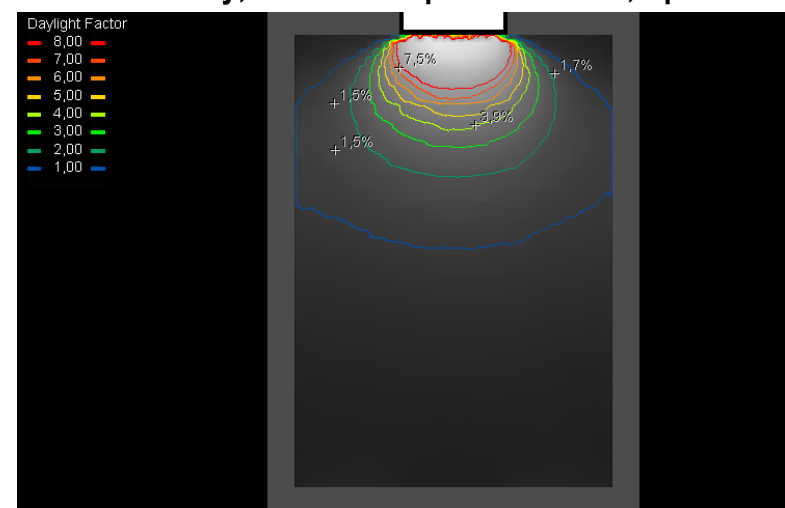

e - overcast sky, southeast view - point A

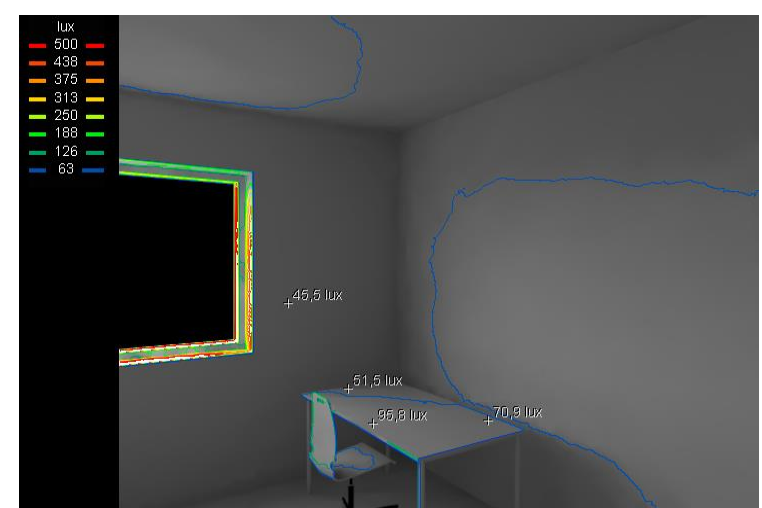

b - sunny sky, southeast view - point A; January

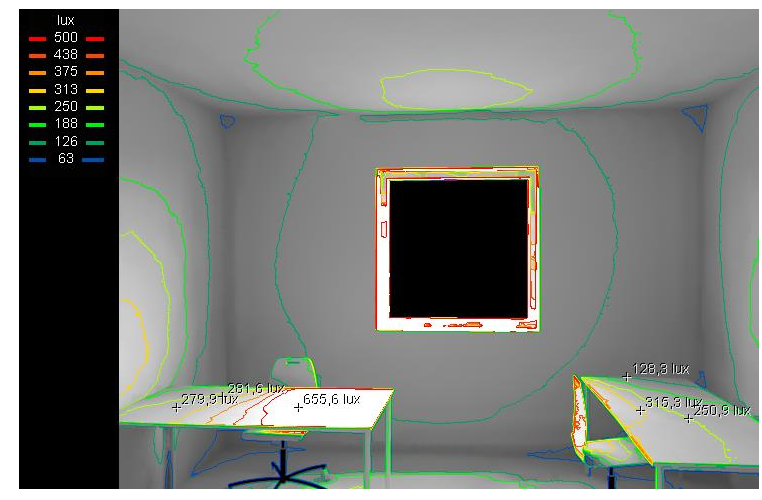

d - sunny sky, south view - points A and B; April

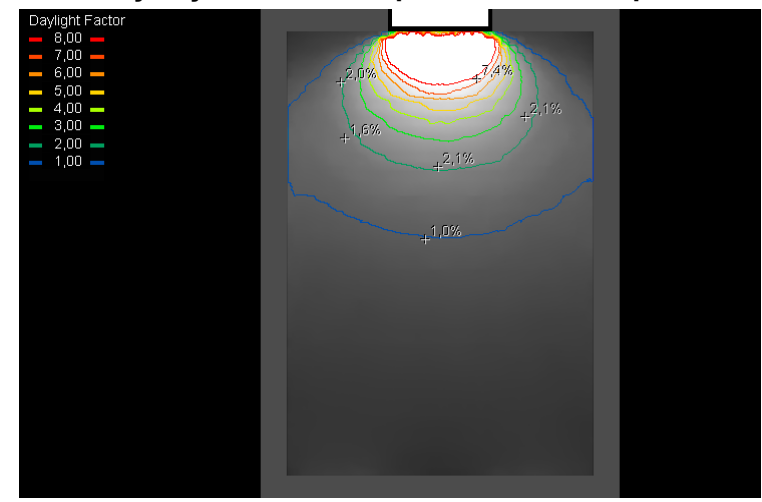

f - overcast sky, south view - points A and B

Figure 12 Results of illumination (Ix) and Daylight Factor (\%) 


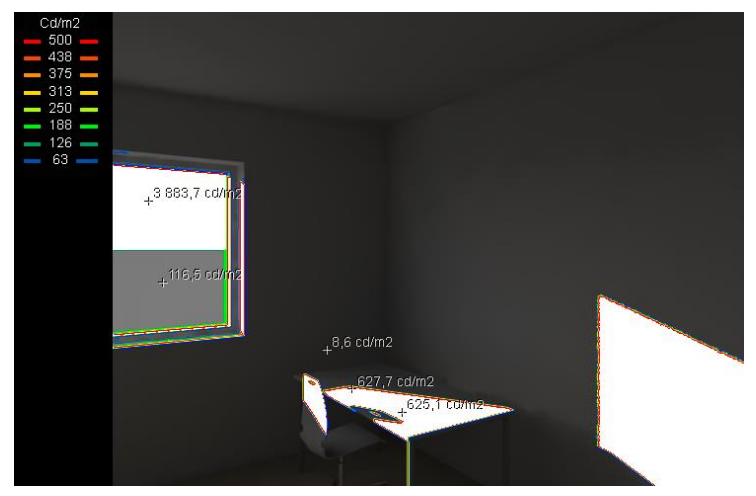

a - sunny sky, southeast view - point A; January

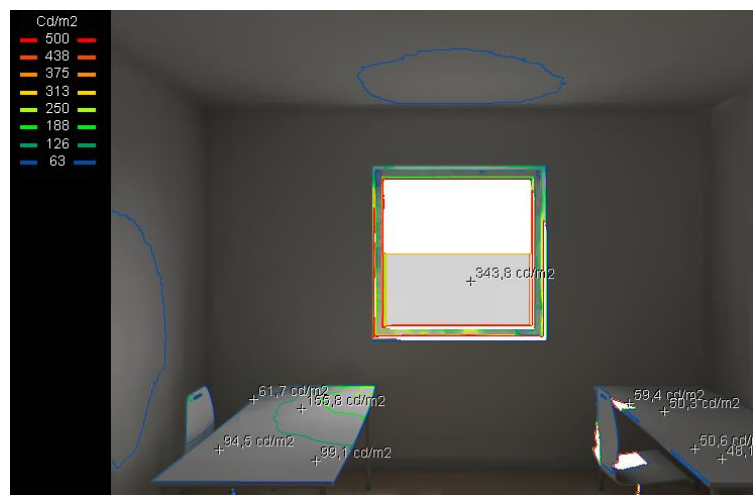

c- sunny sky, south view; table position C; April

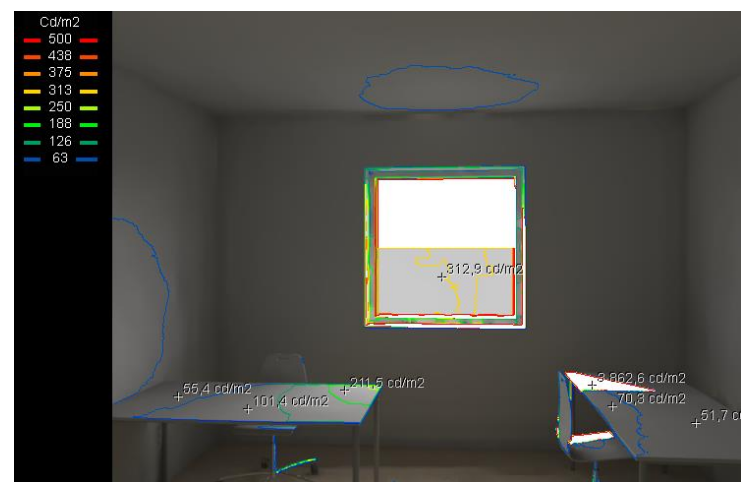

b - sunny sky, south view; points A and B; April

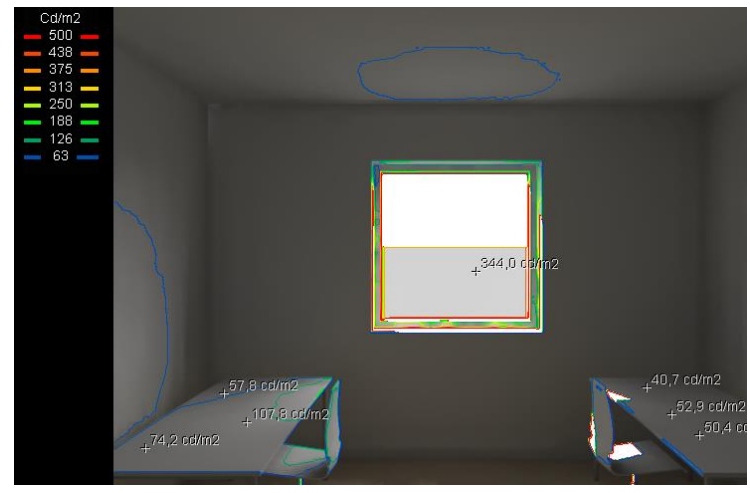

d - sunny sky, south view; table position D; April

Figure 13 Results of luminance level $\left(\mathrm{cdm}^{-2}\right)$

\section{CONCLUSION}

The provision of natural daylight within the built environment can deliver genuine and positive benefits to the finished construction; benefits that can enhance the financial and environmental performance of the building, benefits that can improve the internal environment and make it a better and more pleasant place. To stimulate the mind and improve concentration, it is important to have the area brightly lit $[15,16]$.

The window in the tested room occupied about approximately $15 \%$ of the floor area. The measured sky conditions rating the gradations of sky luminance in January and February-March are shown in Figure 5 (according to standard ratio $L_{e} / L_{z}$ at $15^{\circ}$ is $0.3-0.6$ and at $45^{\circ}$ is $0.7-0.85$ ).

The results (Table 3,4, and Figure 10,12) show that a zone with sufficient illumination reaches only about one third of the depth of the place where both places are located. Comparing points $A$ and $B$ shows that point $A$ has more light in terms of the quantity of light (it expresses the parameter DF). Glare occurs both at points $A$ and $\mathrm{B}$ (Figure $13 \mathrm{a}-\mathrm{b}$ ), especially in the morning; however they are suitable in the afternoon. Based on the results, the appropriate position of the $\mathrm{PC}$ can be determined by position $\mathrm{C}$ (Figure $13 \mathrm{c}$ ), that has good visual comfort and no glare. Positions A and B need glare protection in the morning (Figure $13 \mathrm{a}-\mathrm{b}$ ). No work with PC can be performed in position $\mathrm{D}$ from $1 \mathrm{pm}$ to $4 \mathrm{pm}$. 


\section{Acknowledgements}

This study was elaborated with the financial support of the research project VEGA 1/0674/18 of the Scientific Grant Agency, the Ministry of Education, Science, Research, and Sport of the Slovak Republic and the Slovak Academy of Sciences.

\section{References}

[1] Li, D.H.W.; Lam J.C. 2001: Evaluation of lighting performance in office buildings with daylighting controls, Energy and buildings, 33 (8), pp. 793-803, https://doi.org/10.1016/S0378-7788(01)00067-6

[2] González, J.; Fiorito, F. 2015: Daylighting design of office buildings: Optimisation of external solar shadings by using combined simulation methods, Buildings, 5(3), pp. 560-580, https://doi.org/10.3390/buildings5020560

[3] Konis, K. 2013: Evaluating daylighting effectiveness and occupant visual comfort in side-lit open-plan office building in San Francisco, Building and Environment, 59, pp. 662-677, https://doi.org/10.1016/j.buildenv.2012.09.017

[4] Berardi, U.; Anaraki, H.K. 2016: The benefits of light shelves over the daylight illuminance in office buildings in Toronto, Indoor and Built Environment, 27(2), pp. 244-262, https://doi.org/10.1177/1420326X16673413

[5] Dan H.W.Li.; Tsang E. K.W. 2008: An analysis of daylighting performance for office buildings in Hong Kong, Energy and buildings, 43 (9), pp. 1446-1458, https://doi.org/10.1016/j.buildenv.2007.07.002

[6] Gilani, S.; O'Brien, W. 2017: A preliminary study of occupants' use of manual lighting controls on private offices. A case study, Energy and Buildings, 159, pp. 572-586, https://doi.org/10.1016/j.enbuild.2017.11.055

[7] Beckmann, P.; Spizzichino, A. 1963: The scattering of Electromagnetic Waves from Rough Surfaces, Pergamon Press Oxford, London, New York.

[8] Integral Lighting. 2015. ČSN 360020; Czech Office of Standards, Metrology and Testing: Prague, Czech Republic. (Sdružené osvětlení - základní požadavky) (in Czech)

[9] EN 12464-1:2012. 2012. Light and Lighting-Lighting of Work Places-Part 1: Indoor Work Places; Slovak Republic Office of Standards, Metrology and Testing: Bratislava, Slovakia

[10] Katunsky, D.; Dolniková, E.; Doroudiani, S. 2017 Integrated lighting efficiency analysis in large industrial buildings to enhance indoor environmental quality, Buildings, 7(2), https://doi.org/10.3390/buildings7020047

[11] STN 730580; Daylighting in buildings, - 1 Basic requirements, $1986-2$; Daylighting of residential buildings, 2000, Slovak Republic Office of Standards, Metrology and Testing: Bratislava, Slovakia; 2000

[12] Ferencikova, M.; Darula, S. 2017: Availability of daylighting in school operating time, Light and Engineering, 25 (2), pp. 71-78.

[13] CEN/TC 169 07/2017; 2017: Daylight in buildings (TC 169 WI 00169068) CEN/TC 169.

[14] Gou, Z.; Lau, S.S.; Qian, F. 2015: Comparison of mood and task performance in naturally-lit and artificially-lit environments, Indoor and Built Environment, 24, pp. 27-36, https://doi.org/10.1177/1420326X13507792

[15] Bellia, L.; Bisegna, F.; Spada, G. 2011: Lighting indoor environment Visual and noon-visual light sources with different spectral power distribution, Building and Environment, 46, pp. 1984-1992, https://doi.org/10.1016/j.buildenv.2011.04.007

[16] Lee, J.H.; Moon, J.W.; Kim, S. 2014: Analysis of occupant's visual perception ti refine indoor lighting environment for office tasks, Energies, 7, pp. 4116-4139, https://doi.org/10.3390/en7074116

Please cite this article as:

Dolnikova, E.: Assessment of daylight in the selected office through simulation programs: a case study, Electronic Journal of the Faculty of Civil Engineering Osijek-e-GFOS, 2019, 18, pp. 82-92, https://doi.org/10.13167/2019.18.8 